\title{
Characteristics of diagenesis, isotopic relations and reservoir properties of the Middle Miocene sandstones in the Carpathian Foredeep (Poland and Ukraine)
}

\author{
Katarzyna JARMOŁOWICZ-SZULC ${ }^{1, *}$, Aleksandra KOZŁOWSKA ${ }^{1}$ and Marta KUBERSKA ${ }^{1}$ \\ 1 Polish Geological Institute - National Research Institute, Rakowiecka 4, 00-975 Warszawa, Poland
}

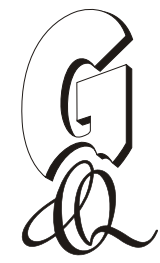

\begin{abstract}
Jarmołowicz-Szulc, K., Kozłowska, A., Kuberska, M., 2015. Characteristics of diagenesis, isotopic relations and reservoir properties of the Middle Miocene sandstones in the Carpathian Foredeep (Poland and Ukraine). Geological Quarterly, 59 (4): 750-761, doi: 10.7306/gq.1261

The Upper Badenian and Sarmatian sandstones recognized from boreholes in southeastern Poland and western Ukraine are very fine to medium-grained subarkosic and sublithic arenites and wackes. The deposits underwent diagenesis well below $100^{\circ} \mathrm{C}$, and their evolutionary pathways of diagenetic and related reservoir properties represent eo- and mesodiagenesis. Eodiagenesis here comprised mechanical compaction, development of chlorite, microcrystalline calcite pyrite, siderite, kaolinite and quartz, and dissolution of feldspar and mica grains. Mesodiagenesis included quartz and K-feldspar overgrowths, albitisation, crystallisation of dolomite and ankerite and coarsely crystalline calcite, dissolution of feldspar grains and carbonate cement, and illite growth. The isotopic data of $\delta^{18} \mathrm{O}_{\mathrm{VPDB}}$ of carbonate cements suggest their crystallisation from porewater which is a mixture of marine and meteoric waters. The $\delta^{13} \mathrm{C}_{\mathrm{VPDB}}$ values suggest derivation of carbon from microbial methanogenesis of organic matter. The ${ }^{87} \mathrm{Sr}{ }^{86} \mathrm{Sr}$ values in coarsely crystalline calcite are higher than those of Badenian seawater. The radiogenic strontium may have been supplied during diagenesis by meteoric waters draining the continental area. The Middle Miocene sandstones show better filtration abilities (good and very good) in the western part of the study area (Poland) than in the east. Primary intergranular porosity is more frequent than secondary intragranular and intercrystalline porosities. The primary porosity was diminished due to compaction and cementation from west to east. Some increase in porosity was caused by dissolution of detrital grains and by decay of soft parts of organisms.
\end{abstract}

Key words: diagenesis, reservoir properties, sandstones, isotopic analyses, Middle Miocene, Carpathian Foredeep.

\section{INTRODUCTION}

Changes in reservoir characteristics of the Middle Miocene strata of the Carpathian Foredeep are important for the interpretation of the geological history and as regards evolution of oil and gas potential and hydrocarbon prospects. Hence, detailed sedimentological, petrological, mineralogical, isotopic and fluid inclusion studies on the Upper Badenian and Sarmatian rocks from southeastern Poland and western Ukraine have been carried out in the last two decades (e.g., Dziadzio, 2000; Maliszewska et al., 2001a, b, 2004; Jasionowski and Peryt, 2010; Jarmołowicz-Szulc et al., 2011; Kozłowska et al., 2011; Kuberska et al., 2011; Lis and Wysocka, 2012; Jasionowski et al., 2012; Wysocka et al., 2012; Peryt et al., 2014; Galamay et al., 2014). Isotopic analysis and particularly strontium isotopic analyses have proven a powerful chronostratigraphic tool (e.g., McArthur et al., 2001, with references therein). Furthermore, isotopic composition of $\delta^{18} \mathrm{O}$ and ${ }^{87} \mathrm{Sr} /{ }^{86} \mathrm{Sr}$ can provide useful information about the origin, mixing processes (Cendón et al.,

\footnotetext{
"Corresponding author, email: katarzyna.jarmolowicz-szulc@pgi.gov.pl
}

Received: January 20, 2015; accepted: November 18, 2015; first published online: November 25, 2015
2008; Garcia-Veigas et al., 2013, 2015, amongst many others) and diagenetic evolution of formation waters (Sheppard, 1986; Schultz et al., 1989; Armstrong-Altrin et al., 2009). However, diagenesis can alter ${ }^{87} \mathrm{Sr} /{ }^{86} \mathrm{Sr}$ ratios from their original values, so a detailed understanding of alteration processes is needed to validate such studies (e.g., Kasprzyk et al., 2007).

Miocene deposits from twenty one boreholes are the subject of the present synthetic study (Fig. 1). Their location is shown in Figure 1.

The aim of the present study is to analyse mineral compositions of the sandstones and their cements and the relationships between various diagenetic processes and the sedimentary environment, and to describe the characteristics of the hydrocarbon reservoir rocks. Attention was focused on observing processes over the entire study area. Over one hundred samples of siliciclastic rock were examined, the results being presented both in earlier works of the authors and in the present paper. These rocks are underlain by the evaporitic succession of the Middle Miocene basin (Oszczypko et al., 2006; Peryt, 2006). Earlier results obtained for the Middle Miocene sandstones from boreholes in the Tarnogród area (Maliszewska et al., 2001a) have been used for comparison and discussion. The presently analysed rock samples are mainly the sandstones referred by Garecka and Olszewska (2011) to the Late Badenian and Sarmatian. 


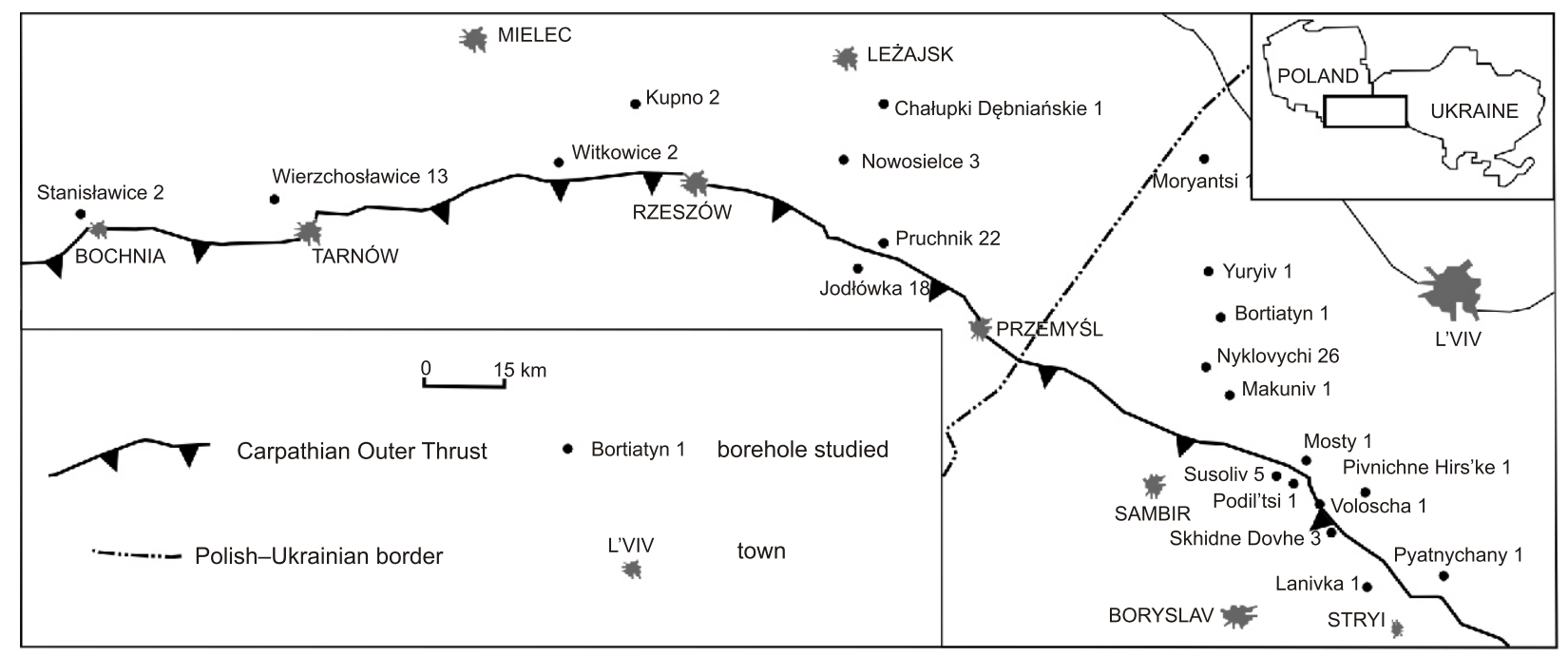

Fig. 1. Location of the boreholes studied in the Carpathian Foredeep

\section{GEOLOGICAL SETTING AND DEPOSITIONAL ENVIRONMENTS}

The Carpathian Foredeep is a large sedimentary basin developed on the Carpathian front from the Danube River in Austria to the Iron Gates in Romania (Oszczypko et al., 2006). The foreland basin developed as a result of Carpathian front movement towards north during Early to Middle Miocene. The inner part of the Carpathian Foredeep is locateed beneath the Carpathian nappes whereas the outer one is placed in front of the orogen (Ney et al., 1974; Oszczypko et al., 2006).

According to seismic, magnetotelluric and borehole data (Oszczypko et al., 2006), the Carpathian Foredeep is asymmetrical as a whole, with an erosional boundary in the north and a tectonic boundary to the south. It is filled in with predominantly clastic strata of Miocene age. The molasse deposits underlain by the basement of the East European Platform are overlain by Permian-Mesozoic terrestrial and shelf strata and locally by Paleogene deposits. The platform basement with the Miocene molasse dips southwards beneath the Outer Carpathian units (Oszczypko et al., 2006). The Early to Middle Miocene Carpathian Foredeep developed as a peripherical foreland basin related to the moving Carpathian front. The Paleozoic-Mesozoic, Paleogene and Neogene strata of the Carpathian Foredeep are oil and gas productive (e.g., Fedyshyn, 1998; Karnkowski, 1999; Kurovets et al., 2004; Kotarba and Koltun, 2006; Kotarba et al., 2007, 2011a, b; Więcław et al., 2012).

The western part of the Polish Carpathian Foredeep Basin is characterized by block structures, and the eastern part by deep erosional structures (canyons; Oszczypko et al., 2006; Peryt, 2012, with references therein; cf. Krzywiec et al., 2014). The siliciclastic deposits (claystones, mudstones and sandstones) reach a thickness of $3 \mathrm{~km}$ in the western part of the study area and up to $6 \mathrm{~km}$ in the eastern section (Oszczypko et al., 2006; Kurovets et al., 2004, respectively). The latest Badenian-Early Sarmatian deposits formed in a variety of depositional environments, from deep marine (basin plain) to shallow marine (Lis and Wysocka, 2012). They represent the Machów Formation in the Polish part (Jasionowski, 1997; Oszczypko et al., 2006) and the Kosiv and Dashava formations in the Ukrainian part (Andreyeva-Grigorovich et al., 2008). In general, the section consists of mudstones and fine-grained sandstones deposited predominantly from gravity flows. Proxi- mal facies contain huge sandstone packages, while the distal ones are dominated by mudstones and claystones with thin sandstone beds. The orogen was the main source area for the material deposited in the Carpathian Foredeep Basin. The sedimentary record is interpreted as terrestrial to marine and consists predominantly of fine-grained sandstones, claystones and mudstones (Peryt and Piwocki, 2004, with references therein). Lis and Wysocka (2012) distinguished fourteen lithofacies in the Middle Miocene deposits within the Polish and Ukrainian parts of the study area. Generally, the sandstones are characteristic of deltaic and shallow marine environments.

\section{METHODS}

53 core samples of sandstones from the depth interval of 300-2500 m from 8 boreholes from Poland and 49 samples from the depth interval of 1250-3200 m from 10 boreholes from Ukraine were collected. Sedimentological descriptions of cores and well-log correlation panels for both parts of the Carpathian Foredeep are given by Lis and Wysocka (2012). Analytical procedures comprised several stages: preparation, microscopic evaluation, petrological and mineralogical assessment and isotopic and fluid inclusion analyses.

All petrological samples were vacuum-impregnated with blue resin prior to thin section preparation in order to investigate, optically, the porosity. Sandstones underwent mineral counting using a counter PRIOR model G. Modal compositions of the sandstones were obtained by counting 300 points per thin section using a polarizing microscope Nikon Eclipse LV 100 $\mathrm{Pol}$. The pore percentage in sandstones was calculated. Sandstone microlithofacies were distinguished using the Pettijohn et al. (1972) classification (a version of the Dott classification, modified). Thin sections were stained by Evamy solution in order to identify the carbonates. Textural features, grains of feldspar and cements of carbonates, quartz and kaolinite were observed in selected polished thin sections analysed within cathodoluminescence $(\mathrm{CL})$ using the equipment with a cold cathode CCL $8200 \mathrm{mk} 3$, Cambridge Image Technology Ltd.

Studies of crystal habit, occurrence and paragenetic relationships were performed on gold-coated samples chips using a LEO 1430 scanning electron microscope (SEM) with energy-dispersive X-ray analyser. Back-scattered electron (BSE) 
images were also obtained with the same SEM. The chemical composition of carbonates and feldspars was determined on twenty-two polished, carbon-coated thin sections using a JEOL JSM-35 scanning electron microscope (SEM) equipped with an energy-dispersive X-ray analyser. Mineralogical composition of the $<2 \mu \mathrm{m}$ fraction of the sediment (clay minerals) was determined by X-ray diffraction (XRD), using a Philips X'Pert PW 3020 diffractometer (Cu K $\alpha$ radiation and semiconductor detector). The analyses were performed on oriented air-dried and subsequently glycol-solvated samples, heated at $550^{\circ} \mathrm{C}$. The fluid inclusion analysis was conducted on authigenic carbonates in selected samples in twenty double-polished thin sections. Thermometric studies were performed using a Linkam THMS600 heating-cooling stage mounted on a polarizing microscope (Nikon Eclipse LV $100 \mathrm{Pol}$ ). In the heating mode they lead to determination of temperatures of mineral crystallisation, since it is assumed that the homogenisation temperature of the primary aqueous inclusions represents a minimum temperature of fluid trapping during mineral precipitation (Roedder, 1984). The estimation of the pressure and temperature conditions of the formation of minerals based on the crossing isochore technique using coexisting carbon dioxide and aqueous inclusions, followed the method introduced by Kalyuzhnyi (1982; Jarmołowicz-Szulc et al., 2011). Isochores for the carbon dioxide were calculated with both the Flincor program (Brown, 1982) and the FLUIDS package (Bakker, 2003).

Carbon and oxygen stable isotope analyses were performed on forty-seven calcite- and eighteen dolomite-cemented sandstone samples. Measurements were conducted at the Maria Curie-Skłodowska University in Lublin (e.g., Hałas, 1982). For the isotopic analyses, carbon dioxide gas was extracted from the samples by reaction of carbonate with $\mathrm{H}_{3} \mathrm{PO}_{4}$ at $50^{\circ} \mathrm{C}$ in a vacuum line for at least 24 hours (according to the procedure by McCrea, 1950). The gas was purified of water on a $\mathrm{P}_{2} \mathrm{O}_{5}$ trap and collected on a cold finger. Isotopic compositions were analysed using a triple collector mass spectrometer equipped with a gas ion source. After subsequent normalization to measured international standards, the isotopic composition was expressed in per mille relative both to VPDB and VSMOW standards. Analytical precision of both $\delta^{13} \mathrm{C}$ and $\delta^{18} \mathrm{O}$ in samples and in standards was better than $\pm 0.08 \%$.

Strontium analyses were performed on eight sandstone samples with carbonate cements (10-15 vol.\% calcite) at the Isotope Geochemistry Laboratory of the Polish Academy of Sciences in Cracow. Standard procedures have been described, e.g., by Peryt et al. (2010), or by Peryt and Anczkiewicz (2015). Powdered rock samples were dissolved on a hot plate in $\mathrm{HCl}$. Dissolved samples were first loaded on a standard cation column (DOWEX 50W-X12 resin). The collected Sr fraction was further purified on Eichrom Sr-spec resin. After converting to nitrates, analyses of the strontium isotopic ratio $\left({ }^{87} \mathrm{Sr} /{ }^{86} \mathrm{Sr}\right)$ were performed in a static mode on the MC ICPMS Neptune with reference to frequent analyses of the SRM987 standard. The measured ratios were instrumentally corrected to fractionation effect using the values of ${ }^{86} \mathrm{Sr} /{ }^{88} \mathrm{Sr}=0.1194$ and normalized with ${ }^{87} \mathrm{Sr} /{ }^{86} \mathrm{Sr}=0.710248$ (Oslick et al., 1994). Precision of individual ratios refers to the last significant digits and is at 2se level (Thirlwall, 1991).

Petrophysical measurements of porosity, permeability and the pore space parameters: porosimetric porosity, the percentage of pores with a diameter $>1 \mu \mathrm{m}$, size of threshold diameter and hysteresis were conducted at the Oil and Gas Institute in Kraków.

\section{SANDSTONE PETROGRAPHY}

The sandstones, as packages or layers of different thickness, form interlayers in thick mudstone-claystone thick successions. Sandstone features for both parts of the study area are shown in Table 1.

\section{FRAMEWORK GRAIN COMPOSITION}

The sandstones are very fine- to medium-grained, moderate to poorly sorted. The grains are angular to subrounded. The sandstones studied represent subarkosic and sublithic arenites and wackes (Fig. 2).

The quartz, the content of which ranges from 18.7 to 70.6 vol. \%, is the main component of the rock (Table 1). Monocrystalline quartz predominates over polycrystalline quartz, which includes fragments of chert (on average $\sim 1$ vol. \%). The quartz grains commonly have sharp edges, and only those of the fraction of $0.25 \mathrm{~mm}$ are partly rounded. Feldspars occur in all sandstone samples analysed in amounts varying from 1.0 to $12.3 \mathrm{vol} . \%$. They are mainly potassium feldspars which show a blue color in cathodoluminescence. The plagioclase, characterized by a green color in CL, is less frequent (Fig. 3A, B). The partial or total replacement of some feldspar grains by albite (non-luminescent in $\mathrm{CL}$ ) and/or calcite as well as dissolution of feldspar is observed (Fig. 3C). Micas occur in various amounts in both segments of the basin, with a distinct muscovite predominance over biotite. Their percentage is low in the east, only occasionally exceeding $10 \mathrm{vol} . \%$. In the western part of the study area, mica content reaches about 18 vol.\%. Lithoclasts occur in the sandstones studied in amounts of up to $11.6 \mathrm{vol} . \%$ in the Ukrainian and up to 18.3 vol. $\%$ in the Polish segments. They are mainly sedimentary rock fragments (mudstones, very fine-grained sandstones, claystones, carbonate rocks in the eastern, and mainly limestones, rarely claystones, siltstones and sandstones in the western part of the basin). The fragments of metamorphic rocks (mica and quartz-mica schists), and the fragments of igneous rocks (granitoids and eruptive rocks, mainly volcanic glass) are less frequent. Calcite bioclasts were observed in the sandstones analysed, from 0 to 3.3 vol.\%. Foraminifers are the most common bioclasts (Fig. 3D), while fragments of bivalve and brachiopod shell and echinoderm and branches of bryozoans are less frequent. Other components of sandstones with $<2$ vol. \% in the sandstones are: organic matter, accessory minerals (mainly zircon and apatite), ooids and glauconite. The glauconite is common and forms oval, green grains of various size that appear affected by varying degrees of chloritisation and pyritisation. Locally, ooids with diameter $<0.5 \mathrm{~m}$ are observed (e.g., the Pruchnik 22 borehole).

Both the matrix and the cement in the Middle Miocene sandstones are present in variable amounts. The matrix is composed of fine grains of quartz mud and detrital flakes of clay minerals, plus locally iron hydroxides, organic matter and pyrite. $\mathrm{XRD}$ analyses of clay minerals have shown the presence of smectite, illite, chlorite and kaolinite. Cements are mainly built of carbonates, while quartz and clay mineral cements are less frequent.

\section{CEMENTS AND REPLACIVE MINERALS}

Various diagenetic minerals in the Middle Miocene sandstones (Fig. 3A, B, E-H) were earlier described by Maliszewska 
Sandstone features in the western and eastern parts of the study area

\begin{tabular}{|c|c|c|}
\hline Sandstone features & Western part (Poland) & Eastern part (Ukraine) \\
\hline Quartz [vol.\%] & 19.0-70.6 & $18.7-68.0$ \\
\hline Feldspar [vol.\%] & $1.7-12.3$ & $1.0-9.3$ \\
\hline Lithoclast [vol.\%] & $\begin{array}{c}0-18.3 \text { (mudstones, very fine grained sand- } \\
\text { stones, claystones, carbonate rocks, rarely } \\
\text { mica schists, quartz-mica shists, granitoids and } \\
\text { volcanic glass) }\end{array}$ & $\begin{array}{l}0.3-11.6 \text { (limestones, rarely claystones, } \\
\text { siltstones, sandstones, mica schists, quartz-mica } \\
\text { schists, granitoids and volcanic glass) }\end{array}$ \\
\hline Micas [vol.\%] & $0-17.7$ & $0-13.3$ \\
\hline Bioclasts [vol.\%] & $0-3.3$ & $0-2.7$ \\
\hline Ooids [vol.\%] & $0-0.7$ & 0 \\
\hline Glauconite [vol.\%] & $0-1.3$ & $0-5.3$ \\
\hline Accessory minerals [vol.\%] & $0-1.7$ & $0-0.7$ \\
\hline Matrix [vol.\%] & $0-49.7$ & $1.7-33.7$ \\
\hline Authigenic quartz [vol.\%] & $0-2.4$ & $0-6.3$ \\
\hline Carbonates [vol.\%] & $\begin{array}{c}3.0-39.7 \\
\text { (calcite, dolomite, ankerite, siderite, rhodochrosite) }\end{array}$ & $\begin{array}{c}4.8-49.3 \\
\text { (calcite, dolomite, ankerite) }\end{array}$ \\
\hline Authigenic clay minerals [vol.\%] & $0-0.3$ & $0-1.7$ \\
\hline$\delta^{13} \mathrm{C}$ in dolomite cement [\% VPDB] & n.d. & $-0.59-2.11$ \\
\hline$\delta^{18} \mathrm{O}$ in dolomite cement [\%o VPDB] & n.d. & $-8.25-(-1.70)$ \\
\hline$\delta^{13} \mathrm{C}$ in calcite cement [\%o VPDB] & $-5.72-(-1.71)$ & $-7.76-(-1.03)$ \\
\hline$\delta^{18} \mathrm{O}$ in calcite cement [\%o VPDB] & $-8.61-(-5.51)$ & $-8.80-(-3.46)$ \\
\hline${ }^{87} \mathrm{Sr} /{ }^{86} \mathrm{Sr}$ in calcite cement & n.d. & $0.708661-0.709255^{*}$ \\
\hline Th $\left[{ }^{\circ} \mathrm{C}\right]$ in calcite cement & $<50$ & $<50$ \\
\hline Salinity wt. \% eq. $\mathrm{NaCl}$ & 13.52 & $7.53-16.24$ \\
\hline Porosity in thin section [vol.\%] & $0-29.4$ & $0-19.3$ \\
\hline Effective porosity [\%] & $14.03-34.76$ & $0.61-28.33$ \\
\hline Pores >1 $\mu \mathrm{m}[\%]$ & $47-91$ & $4-90$ \\
\hline Threshold diameter $[\mu \mathrm{m}]$ & $3-50$ & $0.2-30$ \\
\hline Hysteresis [\%] & $21-84$ & $43-82$ \\
\hline Permeability [mD] & $0.62-332.27$ & $0.10-294.40$ \\
\hline
\end{tabular}

Data from Jarmołowicz-Szulc et al. (2011), Kozłowska et al. (2011) and Kuberska et al. (2011); * new data; n.d. - not determined

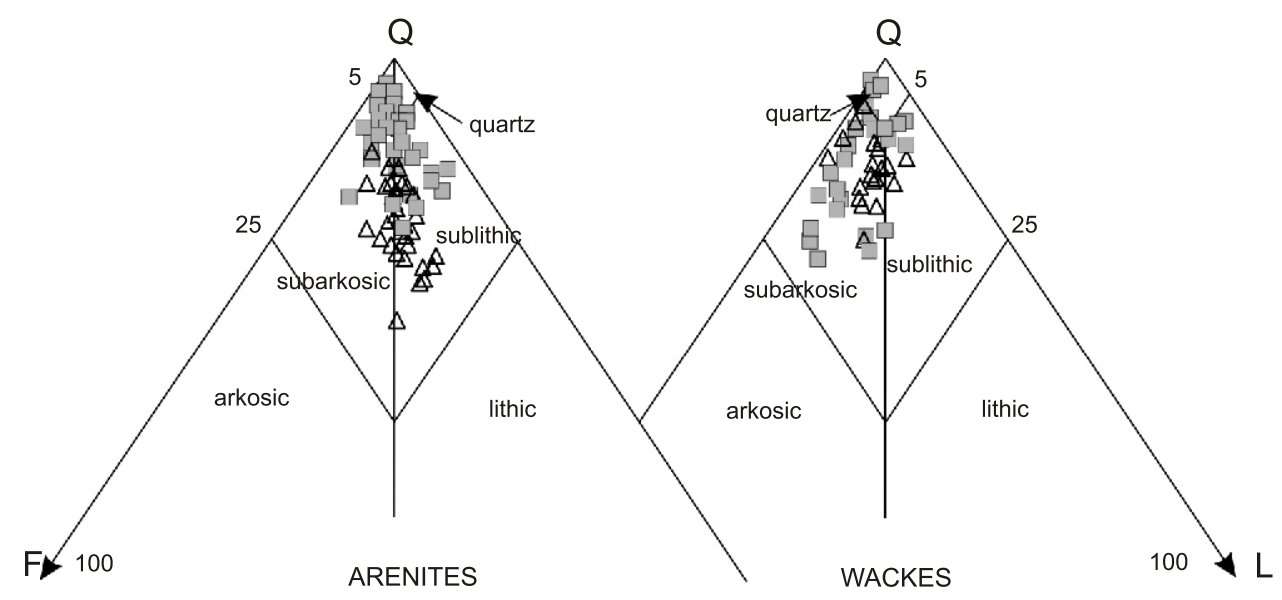

$\triangle$ samples in the western area

$\square$ samples in the eastern area

Fig. 2. Plot of the mineral composition of the Miocene sandstone (arenites, wackes) samples in the classification triangle of Pettijohn et al. (1972); data from Kozłowska et al. (2011) and Kuberska et al. (2011) 

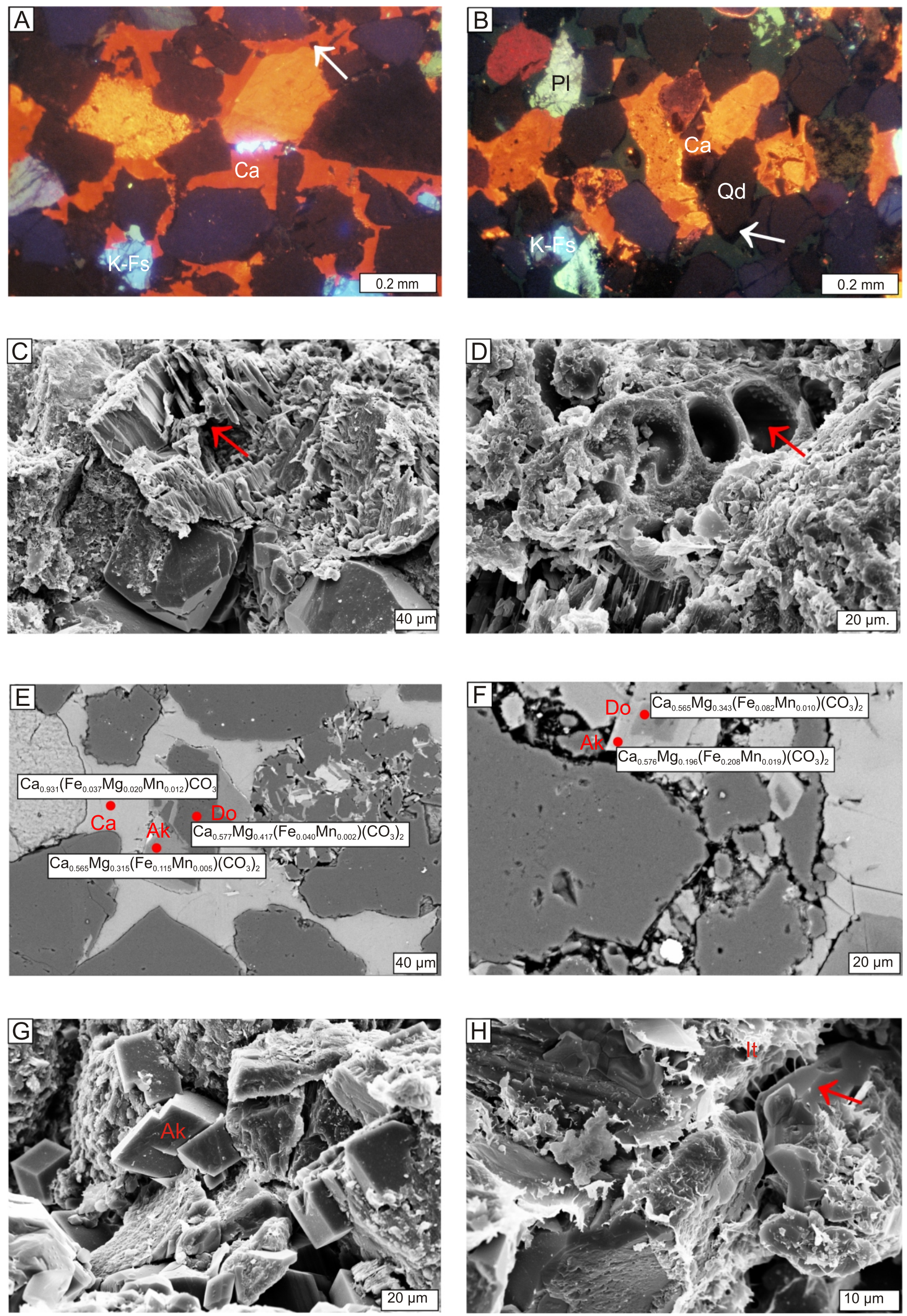
et al. (2001a, b), Kozłowska et al. (2011) and Kuberska et al. (2011).

The carbonate cements in the study area are represented mostly by calcite, dolomite and ankerite (Figs. 4-9). The siderite was identified only in the western part of the study area. Two types of the calcite cement can be distinguished: micro- and coarsely crystalline. The microcrystalline calcite occurs on the surface of grains and in primary pores. The coarsely crystalline to poikilotopic calcite cement occurs in intergranular and intragranular position in the sandstones studied (Fig. 3A, B). Additionally, this cement replaces feldspar grains and rock fragments, often forming pseudomorphs. The coarsely crystalline calcite post-dates quartz overgrowths and dolomite and ankerite rhombohedra (Fig. 3E). The chemical composition of calcite is: $92.2-99.4$ mol. $\% \mathrm{CaCO}_{3}, 0-4.6 \mathrm{~mol} \% \mathrm{FeCO}_{3}, 0-2.5 \mathrm{~mol} . \%$ $\mathrm{MgCO}_{3}$ and $0-2.5$ mol. $\% \mathrm{MnCO}_{3}$ (Fig. 4). It represents mainly Fe-bearing calcite characterized by red-orange and orange-yellow colors in CL (Fig. 3A, B). The $\delta^{18} \mathrm{O}$ values for calcite range from -8.80 to $-3.46 \%$ VPDB, and the $\delta^{13} \mathrm{C}$ values from -7.76 to $-1.03 \%$ VPDB (Table 1; Figs. 5 and 6). Strontium values in the calcite are shown in Tables 1 and 2, Figures 8 and 9. The ${ }^{87} \mathrm{Sr} /{ }^{86} \mathrm{Sr}$ ratios in the sandstones studied with predominantly calcite cements range from 0.708661 to 0.709255 (2se of 0.000011 , Table 2; Figs. 8 and 9). Fluid inclusions in the calcite cement in the sandstones are mostly one-phase and either clear transparent or dark in colour. Their size ranges from 1 to 2 $\mu \mathrm{m}$. The one-phase character of the inclusions indicates low temperatures of cement formation - at about $50^{\circ} \mathrm{C}$ (Shephard et al., 1985; Burruss et al., 1987; Jarmołowicz-Szulc et al., 2011). The dolomite and the ankerite occur in sandstones as pore-filling rhombohedra (Fig. 3A, E-G). Some of the crystals show zoning, with the core poorer in iron than the rims. The chemical composition of the dolomite minerals is: 52.4-61.4 mol.\% $\quad \mathrm{CaCO}_{3}, \quad 18.1-45.0 \quad \mathrm{~mol} . \% \quad \mathrm{MgCO}_{3}$, 0-21.0 mol. $\% \mathrm{FeCO}_{3}$ and $0-2.0$ mol. $\% \mathrm{MnCO}_{3}$ (Fig. 4). The dolomite and ankerite crystals are surrounded by Fe-bearing calcite. The $\delta^{18} \mathrm{O}$ values for dolomite are between -8.25 and $-1.70 \%$ VPDB, while the $\delta^{13} \mathrm{C}$ values range from $-0.59-+2.11 \%$ o VPDB (Table 1; Figs. 5 and 7 ). The siderite occurs as scattered microcrystalline crystals. Siderite varies widely in composition, being enriched in magnesium, and represents sideroplesite (Fig. 4).

The quartz cement occurs commonly in amounts below $1 \mathrm{vol} . \%$ of the whole rock, only rarely reaching up to $2.4 \mathrm{vol} . \%$. It occurs as partial or complete syntaxial overgrowths around the quartz grains. The boundary between the overgrowths and the detrital core is either poorly defined or delineated by fluid inclusions or thin clay coatings. The quartz overgrowths show dark-brown luminescence or no luminescence, while the quartz grains have brown and blue colors (Fig. 3B). The authigenic

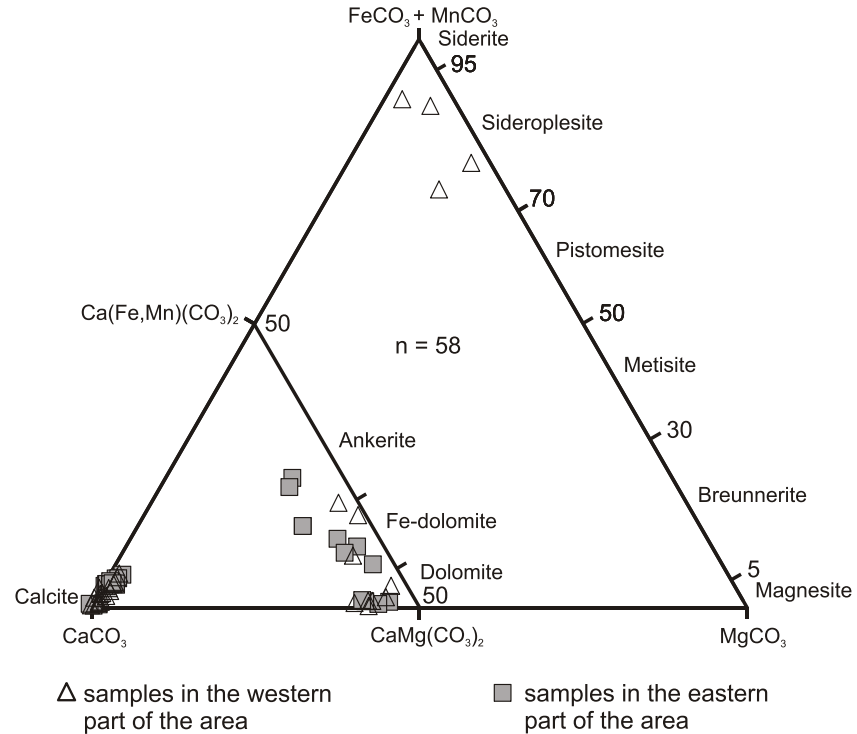

Fig. 4. Plot of the elemental composition of $\mathrm{CaCO}_{3}, \mathrm{MgCO}_{3}$ and $\mathrm{FeCO}_{3}+\mathrm{MnCO}_{3}(\mathrm{~mol} . \%)$ for the carbonate cements from microprobe analyses; data from Kozłowska et al. (2011) and Kuberska et al. (2011)

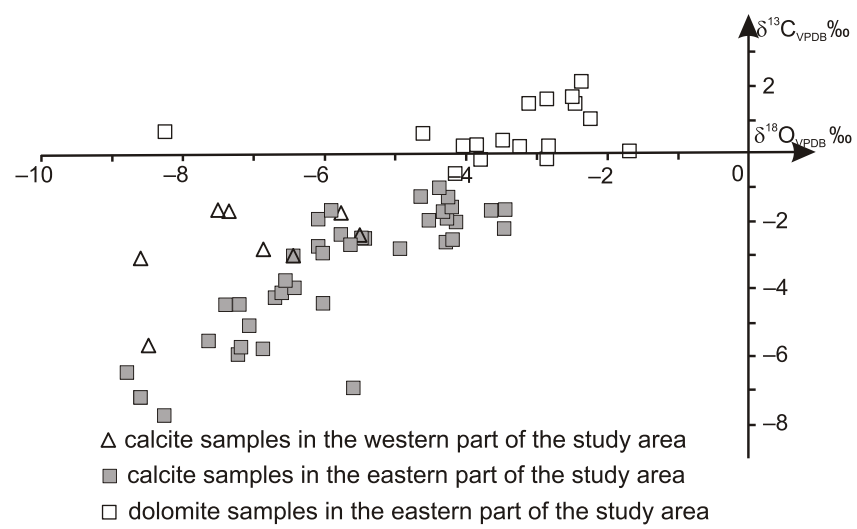

Fig. 5. Plot of the data obtained for calcite and dolomite samples from the carbonate cements in the $\delta^{18} \mathrm{O}_{\mathrm{VPDB}}$ versus $\delta^{13} \mathrm{C}_{\mathrm{VPDB}}$ diagram; data from Kozłowska et al. (2011) and Kuberska et al. (2011)

quartz overgrowths are rhombohedral crystals and prisms on detrital quartz grains as observed in SE images (Fig. $3 \mathrm{H}$ ).

The authigenic clay minerals observed under the polarizing and scanning electron microscopes are kaolinite, chlorite and illite. The kaolinite occurs as booklets and vermicular stacked

\section{Fig. 3. Photographs in cathodoluminescence $(C L)$ and scanning electron microscope (SE, BSE) modes}

A - fragment of sandstone, CL image, orange and yellow-orange luminescence of calcite cement (Ca) and no luminescence of rhombohedra of ankerite (arrow), blue luminescence of potassium feldspar (K-Fs), Jodłówka 8 borehole, depth 2406.0 m; B - fragment of sandstone, CL image, non-luminescent quartz overgrowths (arrow) on brown quartz grain (Qd), orange and yellow-orange luminescence of calcite cement (Ca), green luminescence of plagioclase (PI) and blue luminescence of potassium feldspar (K-Fs), Jodłówka 8 borehole, depth 2403.5 m; C secondary porosity resulting from dissolution of feldspar (arrow), Jodłówka 18 borehole, depth 2403.5 m, SE image; D - secondary porosity in foraminifer shell (arrow), Jodłówka 18 borehole, depth 2104.4 m, SE image; E - dolomite grain (Do) with ankerite (Ak) outer layer engulfed by calcite cement $(\mathrm{Ca})$, skhidne Dovhe 3 borehole, depth $1726.9 \mathrm{~m}$, BSE image; F - rhombohedra of dolomite (Do) with ankerite (Ak) in the outer parts. Nyklovychi 26 borehole, depth 1249.7 m, BSE image; G - rhombohedra of ankerite (Ak) in pore space of sandstone, Jodłówka 18 borehole, depth 2403.5 m, SE image; H - fibrous illite (It) filling in sandstone pore space and prismatic authigenic quartz (arrow), Jodłówka 18 borehole, depth $1912.6 \mathrm{~m}$, SE image 


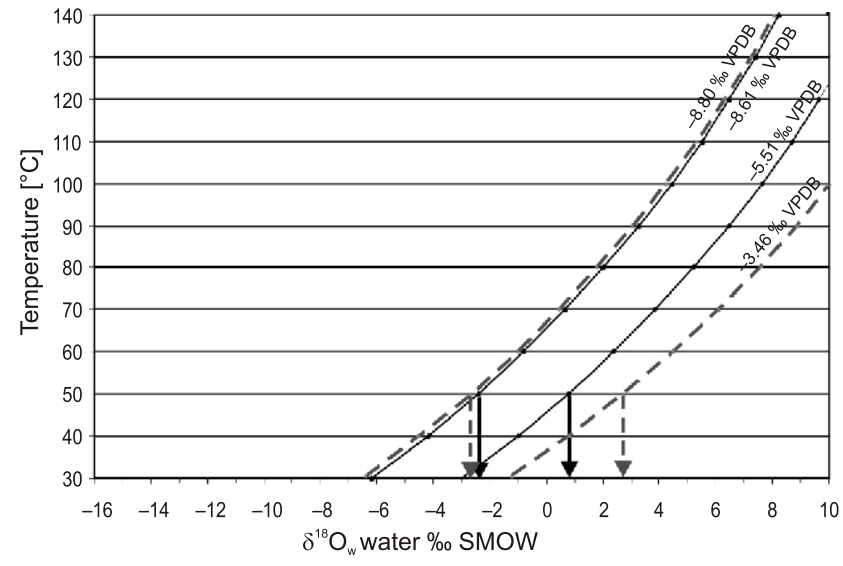

$\delta^{18} \mathrm{O}$ of calcite maximum and minimum values

of studies samples from western part of the area

- $\quad \delta^{18} \mathrm{O}$ of calcite maximum and minimum values

of studies samples from eastern part of the area

Fig. 6. Plot of the results obtained from pore water in the calcite cement in the $\delta^{18} \mathrm{O}$ versus temperature diagram (see Friedman and O'Neil, 1977); data from Kozłowska et al. (2011) and Kuberska et al. (2011); temperature of $50^{\circ} \mathrm{C}$ obtained from $\mathrm{FI}$ (Jarmołowicz-Szulc et al., 2011)

pseudohexagonal crystals, the latter being locally distributed in intergranular and intragranular space of the Middle Miocene sandstones. Blocky habits were also noticed in some samples. The kaolinite is surrounded by quartz overgrowths, so it pre-dates the quartz. Rarely, it replaces detrital feldspar or muscovite. Chlorite was identified only locally. Chlorite/chlorite-smectite minerals occur as small flakes developed into a honeycomb-like texture that coats the framework grains. Iron content is there higher than that of magnesium (Kozłowska et al., 2011). Platy and filamentous crystals of illite cover the authigenic quartz and calcite and infill the pore space in the sandstone (Fig. $3 \mathrm{H}$ ).

Minor diagenetic minerals include pyrite, feldspars and rhodochrosite. The pyrite occurs as scattered framboids filling primary and secondary pores (dissolved bioclasts) in the rock. Authigenic K-feldspars occur as overgrowths on partly to completely albitised and argillitised plagioclase grains. These overgrowths are surrounded by, and hence pre-date, the quartz overgrowths. The rhodochrosite in nodules was identified only in samples from the western part of the area.

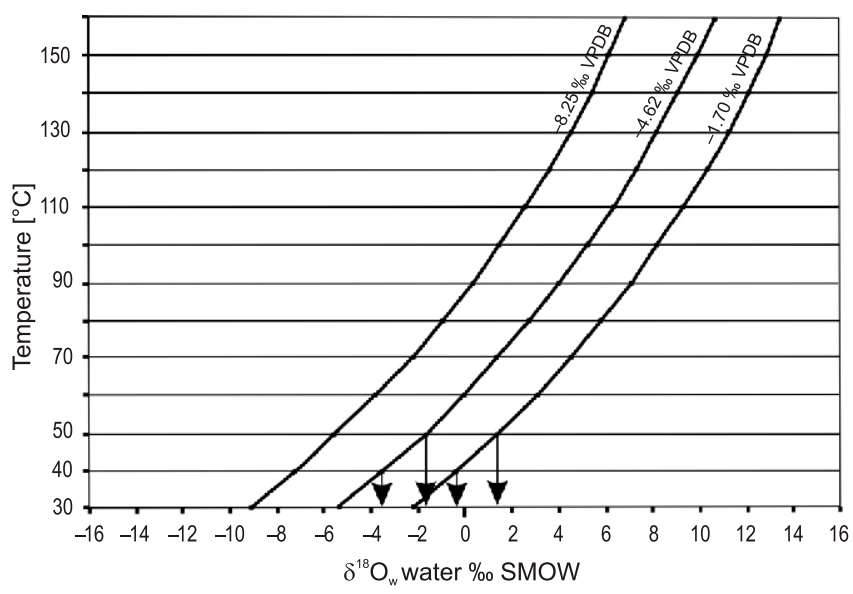

Fig. 7. Plot of the results obtained from pore water in the dolomitic cement in the $\delta^{18} \mathrm{O}$ versus temperature diagram (see Dutton and Land, 1985); data from Kuberska et al. (2011)

\section{INTERPRETATION AND DISCUSSION}

\section{EVOLUTIONARY PATHWAYS OF DIAGENESIS}

In the present paper, a classification of diagenetic stages after Choquette and Pray (1970) has been applied. As shown below, two diagenetic stages (eo- and mesodiagenesis) have been distinguished.

The eodiagenesis corresponds both to the formation of clay mineral rims (mostly chlorite rims on the detrital grains) and mechanical compaction, observed as undulose mica flakes or as local grain re-arrangement. At this stage the crystallisation of the microcrystalline calcite and, locally, of the siderite and the pyrite started. The preliminary alteration stages of unstable components of the grain fabric (such as micas and feldspars) led to the kaolinite formation. Temperatures of the kaolinite formation may be determined as $25-50^{\circ} \mathrm{C}$ (Osborne et al., 1994). The precipitation of silica may have also started at this temperature.

In the mesodiagenesis, the authigenic quartz overgrowth formation on quartz grains continued. Feldspar overgrowths on the detrital feldspar grains were formed after the quartz and prior to coarsely crystalline calcite cements. The dolomite and

$$
\text { Table } 2
$$

Strontium isotopic data obtained for calcite cement in comparison to carbon and oxygen data for the eastern part of the study area

\begin{tabular}{|l|c|c|c|c|c|}
\hline \multicolumn{1}{|c|}{ Borehole } & $\begin{array}{c}\text { Depth } \\
{[\mathrm{m}]}\end{array}$ & $\begin{array}{c}\delta^{13} \mathrm{C} \\
{\left[\%{ }^{\mathrm{VPDB}}\right]}\end{array}$ & $\begin{array}{c}\delta^{18} \mathrm{O} \\
{\left[\%{ }^{\mathrm{VPDB}}\right]}\end{array}$ & ${ }^{87} \mathrm{Sr} /{ }^{86} \mathrm{Sr}$ & $\begin{array}{c}\text { 2se } \\
\text { (measurement precision) }\end{array}$ \\
\hline Lanivka 1 & 1456.3 & -2.40 & -5.76 & 0.708842 & 0.000011 \\
\hline Makuniv 1 & 1847.0 & -5.55 & -7.66 & 0.708927 & 0.000011 \\
\hline Nyklovychi 26 & 1250.5 & -1.30 & -4.66 & 0.708661 & 0.000011 \\
\hline Nyklovychi 26 & 1701.3 & -4.39 & -7.19 & 0.708859 & 0.000009 \\
\hline Podil'tsi 1 & 1231.8 & -5.95 & -7.24 & 0.708823 & 0.000011 \\
\hline Skhidne Dovhe 3 & 1714.3 & -7.76 & -8.27 & 0.708953 & 0.000009 \\
\hline Skhidne Dovhe 3 & 1726.9 & -6.56 & -8.80 & 0.708887 & 0.000012 \\
\hline Susoliv 5 & 2100.5 & -1.95 & -6.11 & 0.708783 & 0.000007 \\
\hline Susoliv 5 & 2528.2 & -2.78 & -6.09 & 0.709255 & 0.000011 \\
\hline Voloscha 1 & 2091.2 & -6.91 & -5.59 & 0.709163 & 0.000011 \\
\hline
\end{tabular}




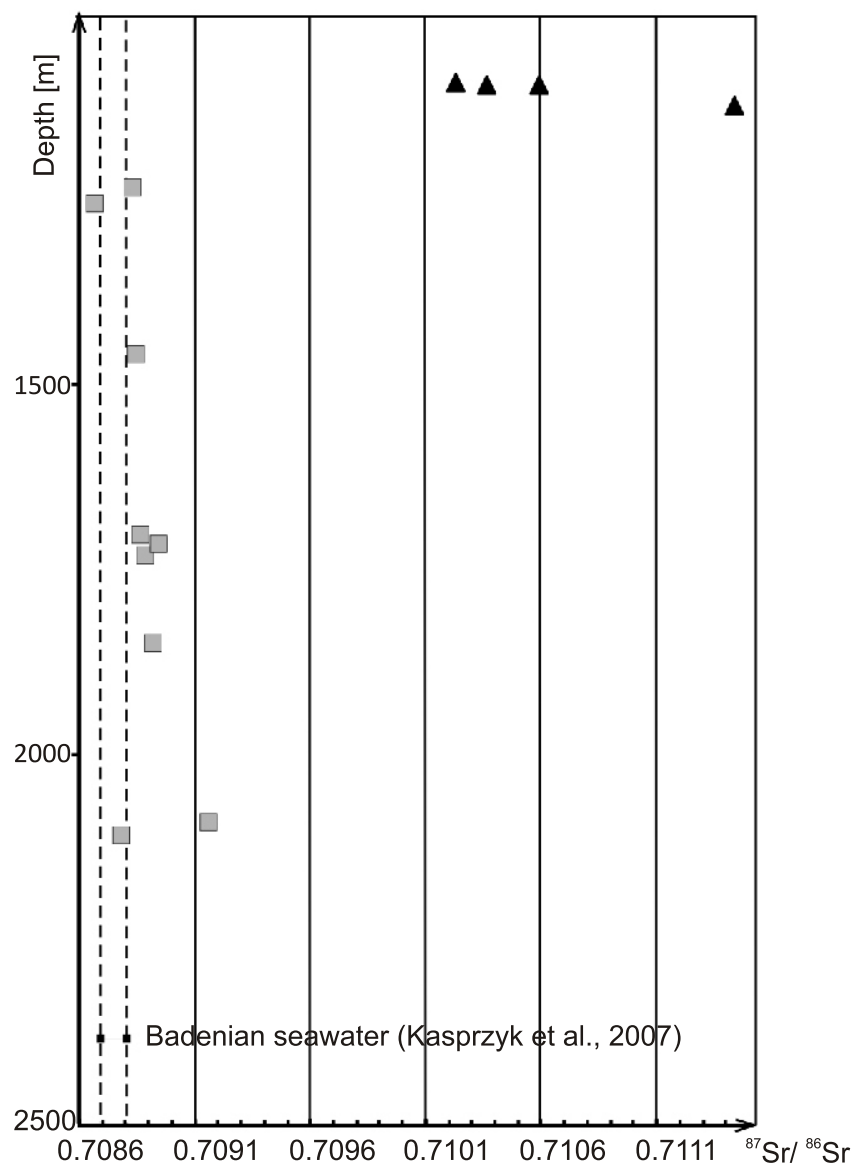

A Polish data from the paper of Jasionowski and Peryt (2010)

$\square$ Ukrainian data - present study

Fig. 8. Variation of the ${ }^{87} \mathrm{Sr} /{ }^{86} \mathrm{Sr}$ ratio in the calcite cements with depth

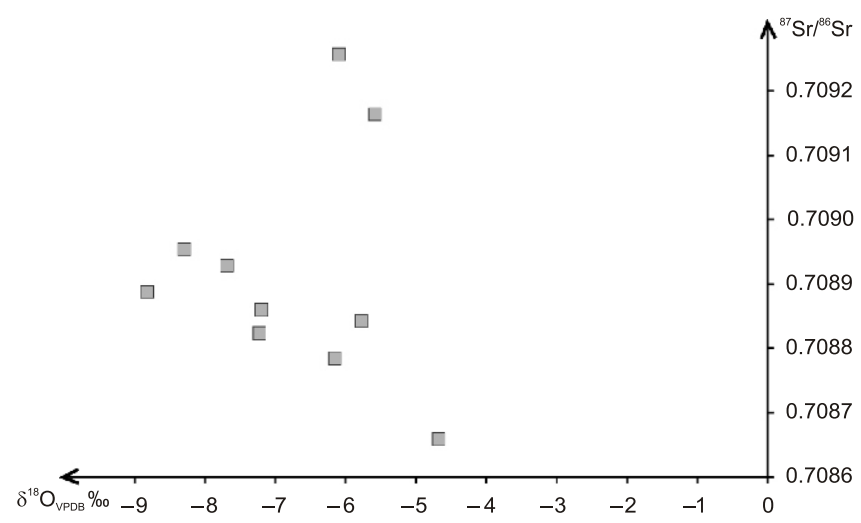

Fig. 9. Plot of the ${ }^{87} \mathrm{Sr}{ }^{86} \mathrm{Sr}$ ratio versus $\delta^{18} \mathrm{O}_{\mathrm{VPDB}}$ in calcite cements

ankerite rhombohedra postdate the quartz overgrowths and pre-date the coarsely crystalline calcite cement, so that cement crystallised at lower temperatures than the calcite, probably not higher than $50^{\circ} \mathrm{C}$.

El-Ghali et al. (2013) suggested a precipitation of dolomite on a Lower Miocene shoreface and on deltaic arenites at temperatures of $20-50^{\circ} \mathrm{C}$ and $42-55^{\circ} \mathrm{C}$, respectively. The dissolu- tion of the calcite cements, the dissolution and albitisation of plagioclases, or the illitisation of the smectite may have been sources for $\mathrm{Ca}$ and $\mathrm{Fe}$ in the coarsely crystalline calcite in the sandstones studied (Boles and Franks, 1979; Milliken, 1998; Morad, 1998). Progressive mesodiagenesis led to a continued dissolution of feldspars, lithoclasts and components of the earlier cements resulting in the formation of secondary, intergranular and intragranular, porosity. Moreover, effects of the illitisation of kaolinite can be observed. The formation of authigenic illite took place at temperatures of about $100^{\circ} \mathrm{C}$ (Kantorowicz, 1990). All these processes have been accompanied by limited compaction.

\section{DIAGENETIC CONDITIONS OF CARBONATE CEMENTATION}

Fluid inclusions $(\mathrm{FI})$ in the calcite cement in the sandstones studied by means of microthermometry indicate a temperature dependence. The eutectic temperature for these inclusions is generally $<-21^{\circ} \mathrm{C}$ and the ice melting temperature is between -6.5 to $-5.9^{\circ} \mathrm{C}$ (see: Jarmołowicz-Szulc et al., 2011). Microthermometric data of the fluid inclusions in the coarsely crystalline calcite cement studied in the west of the area (e.g., in the Pruchnik 22 borehole; Kozłowska et al., 2011) point to low temperatures of cement formation $-<50^{\circ} \mathrm{C}$ (Shephard et al. 1985; at maximum $80^{\circ} \mathrm{C}$, Jarmołowicz-Szulc et al., 2011). The eutectic temperatures suggest the $\mathrm{NaCl}-\mathrm{CaCl}_{2}-\mathrm{MgCl}_{2}-\mathrm{H}_{2} \mathrm{O}$ system, while the ice melting temperature indicates fluid salinity of 13.52 wt.\% NaCl eq. (Brown, 1982; Burruss, 1987; Bodnar, 1990; Jarmołowicz-Szulc et al., 2011). In the eastern part of the study area, the microthermometric results of one-phase inclusions (Skhidne Dovhe 3, Lanivka 1) suggest salinities of $\sim 9$ wt. $\% \mathrm{NaCl}$ eq., densities of $\sim 1.1 \mathrm{~g} / \mathrm{cm}^{3}$ trapping conditions $<60^{\circ} \mathrm{C}$ and pressures of about 375 bars (see Jarmołowicz-Szulc et al., 2011).

\section{CARBON AND OXYGEN ISOTOPES}

The generally positive $\delta^{13} \mathrm{C}$ values of dolomite in the study area in Ukraine in the interval from -0.59 to $2.11 \%$ VPDB and its enrichment in iron suggest derivation of the carbon from microbial methanogenesis of organic matter (Burns et al., 1988; Morad, 1998). The $\delta^{18} \mathrm{O}$ values for dolomite change most frequently from -4.0 to $-2.0 \%$ VPDB (Jarmołowicz-Szulc et al., 2011; Kuberska et al., 2011). From the fractionation equation of Dutton and Land (1985) the authors have used $\delta^{18} \mathrm{O}$ values (mainly from -4.62 to $-1.70 \%$ VPDB) and assumed a crystallisation temperature of about $40-50^{\circ} \mathrm{C}$ (Fig. 7). The data indicate the precipitation of dolomite from porewater showing $\delta^{18} \mathrm{O}$ VSMOW values between about -3.5 to $1.0 \%$ which further points to a mixture of marine and meteoric waters. El-Ghali et al. (2013) obtained similar isotopic compositions of porewater and they assumed that dolomite precipitated from brackish to marine porewaters.

The $\delta^{13} \mathrm{C}$ values of calcite, with an average of about $-4.0 \%$ VPDB, suggest the microbial methanogenesis of organic matter as a source of the carbon. The $\mathrm{FeCO}_{3}$ content in calcite (0.0-4.6 mol.\%; average $2.0 \mathrm{~mol} . \%)$ suggests precipitation in the suboxic zone where the porewaters were depleted in oxygen during progressive burial (El-Ghali et al., 2013). According to Glasmann et al. (1989), the high iron and manganese concentrations in the calcite indicate precipitation from pore waters in reducing conditions. The $\delta^{18} \mathrm{O}$ values for calcite change from -8.80 to $-3.46 \%$ VPDB. If the fractionation equation of Friedman and O'Neil (1977) is adopted, a temperature of $50^{\circ} \mathrm{C}$ for precipitation of the coarsely crystalline calcite is indicated 
(Fig. 6).The $\delta^{18} \mathrm{O}$ calculation results in the calcite indicate the precipitation of this calcite from porewater which was a mixture of marine and meteoric waters. This further suggests some differentiation of $\delta^{18} \mathrm{O}$ VSMOW in the porewaters of $(-2.5$ to $1.0 \%$ ) and $(-2.5$ to $3.0 \%)$ from the west to the east, respectively. The meteoric or mixed, i.e., meteoric and marine waters, could have been a source for the carbonates. Czapowski (1976), Hałas (1982) and Kurzawa (1990) have already described selective carbonate cementation in the Miocene deposits in Poland, although in another geological context than given in the present paper.

\section{STRONTIUM ISOTOPES}

A certain relationship between the ${ }^{87} \mathrm{Sr} /{ }^{86} \mathrm{Sr}$ ratio $(0.708661$ to 0.709255 ) in calcite and the sampling depth can be noticed (Fig. 8 and Table 2). In general, the deeper is the sample, the higher are the values of isotopic ratios. The points corresponding to ${ }^{87} \mathrm{Sr} /{ }^{86} \mathrm{Sr}$ values seen in the figure (Fig. 8) plot on an almost linear trend for the Ukrainian samples, with one exception (the sample from the Podil'tsi borehole). The samples show distinctly lower values than those obtained by Jasionowski and Peryt (2010) for the calcite from the anhydrite succession of the Wola Różaniecka borehole. The ${ }^{87} \mathrm{Sr} /{ }^{86} \mathrm{Sr}$ ratios for the carbonates from the depth between 1112.9 and $1118.8 \mathrm{~m}$ are between 0.710276 and 0.71148 . In that context, a decreasing tendency eastwards may be observed in regional comparisons of the strontium ratios in carbonates. The present paper data (0.708661 to 0.709255$)$ also differ from the ${ }^{87} \mathrm{Sr} /{ }^{86} \mathrm{Sr}$ value reported by Dickson et al. (2001) for contemporaneous marine carbonates. According to Schultz et al. (1989), the carbonate cements have the same strontium ratio as those of the pore water at the time they precipitated. The ratio of ${ }^{87} \mathrm{Sr} /{ }^{86} \mathrm{Sr}$ of seawater during the Late Miocene to Early Pliocene lies between 0.7089 and 0.7091 (Hodell et al., 1991). According to McArthur et al. (2001) depicted ${ }^{87} \mathrm{Sr} /{ }^{86} \mathrm{Sr}$ ratio variation in the Phanerozoic, seawater values lower than about 0.7083 were characteristic for the time period from the Early Devonian to the earliest Miocene. The ${ }^{87} \mathrm{Sr} /{ }^{86} \mathrm{Sr}$ ratio value in the Badenian seawater is reported as 0.708698-0.708817 (Kasprzyk et al., 2007). The samples studied show average ${ }^{87} \mathrm{Sr} /{ }^{86} \mathrm{Sr}$ ratios values of about 0.708915 , which is higher than those of the Badenian seawater quoted above. This difference can suggest that the calcium cements were formed from brines containing non-marine $\mathrm{Sr}$, or with significant meteoric water inputs, and also by bacterial sulphate reduction. In general, the non-marine waters are characterized by higher ${ }^{87} \mathrm{Sr} /{ }^{86} \mathrm{Sr}$ values as compared with values of the normal Miocene seawater (Palmer and Edmond, 1989). In a closed basin system, the local, altered plagioclase and smectite could have been a possible source of strontium for the calcite which crystallised at a later stage of diagenesis. The ${ }^{87} \mathrm{Sr} /{ }^{86} \mathrm{Sr}$ ratios in plagioclase (average of $\sim 0.70663$ ) are lower than those in smectite (average of $\sim 0.71073$ ) which can affect the ${ }^{87} \mathrm{Sr} /{ }^{86} \mathrm{Sr}$ value in calcite (Schultz et al., 1989). In the calcite studied, there is an increase in strontium ratios as compared with the Badenian seawater values.

In the present case, therefore, the plagioclase cannot be a source of strontium. The samples studied have higher ${ }^{87} \mathrm{Sr} /{ }^{86} \mathrm{Sr}$ ratios than the contemporary seawater, indicating a significant input of the radiogenic ${ }^{87} \mathrm{Sr}$ to the system after deposition (Armstrong-Altrin et al., 2009). The radiogenic strontium may have been supplied during diagenesis by meteoric waters draining the continental area. Glasmann et al. (1989) stated that the high radiogenic strontium level indicates an interaction of the pore-fluid with continental silicates. As shown in Figure 9, there is a general trend towards higher negative $\delta^{18} \mathrm{O}$ and higher ${ }^{87} \mathrm{Sr} /{ }^{86} \mathrm{Sr}$ ratios. This confirms that continental waters or a mixture of marine and continental waters were responsible for these relationships.

Such an interpretation is in agreement with the values of ${ }^{87} \mathrm{Sr} /{ }^{86} \mathrm{Sr}$ ratios obtained recently in the Badenian primary gypsum from two boreholes in the Polish Carpathian Foredeep Basin (Peryt and Anczkiewicz, 2015) and with the fluid inclusion and isotopic studies in the Badenian evaporates that suggest a mixed marine /meteoric origin for brines resulting in evaporite precipitation (Céndon et al., 2008). Peryt and Anczkiewicz (2015) found out that strontium ratios are higher than the contemporary seawater value due to significant non-marine contribution of radiogenic strontium. The high-grade Archean and Paleoproterozoic igneous rocks of the Ukrainian shield are regarded as the source of the higher ${ }^{87} \mathrm{Sr} /{ }^{86} \mathrm{Sr}$ ratios recorded in the primary gypsum.

\section{DIAGENESIS AND POROSITY}

The porosity and the permeability data obtained for numerous Polish and Ukrainian sandstone samples shows variability as shown by Kozłowska et al. ( 2011) and Kuberska et al. (2011) and in Table 1. The results of laboratory determinations of effective porosity factor oscillate from 0,61 to $34.76 \%$. According to the classification of Jenyon (1990), the Middle Miocene sandstones can be regarded as having a good and a very good porosity. Curves of capillary pressure were constructed and a threshold diameter determined (from 0 to $50 \mu \mathrm{m}$ ). Values of $<3 \mu \mathrm{m}$ indicate very low properties, while higher values point to good or very good filtration abilities of the sandstones analysed. The values of the hysteresis change in general from 21 to $84 \%$, being less scattered eastwards. From analysis of these values some regularity in development of the pore space may be noticed. The percentage of pores with a diameter $>1 \mu \mathrm{m}$ varies and changes from 4 to $91 \%$ (exceeding $50 \%$ in most samples). The majority of the Ukrainian samples show a low permeability $-<1 \mathrm{mD}$. In some samples the permeability is of some dozens $\mathrm{mD}$, occasionally $>200 \mathrm{mD}$. On the other hand, most of the Polish samples are characterized by a very high permeability, above $100 \mathrm{mD}$, according to the classification of Levorsen (1956).

The porosity measured in thin sections reaches at maximum 19.3.vol\% (in the eastern part of the area studied) and $29.4 \mathrm{vol} . \%$ in the west and corresponds mainly to a primary intergranular porosity. Secondary intragranular pores were primarily associated with the dissolution of detrital feldspars (Fig. 3C) and rock fragments and minor bioclasts and calcite cement. Some secondary pores are inside foraminifer shells (Fig. 3D). Intercrystalline porosity (micropores) may be associated with the presence of clays.

A successive deterioration of porosity in the sandstones studied with increasing depth is observed (Kozłowska et al., 2011; Kuberska et al., 2011). The primary porosity of sandstones decreased due to compaction and cementation. Later, it increased by dissolution.

The mechanical compaction includes grain re-arrangement and plastic deformation of mica and ductile grains. Point and linear contacts between quartz grains were the only ones observed in the sandstones. The carbonates, the quartz and the authigenic clay minerals play the most significant role among the cements of the sandstones. The calcite cement is predominant. Locally, it strongly reduces the porosity and decreases permeability down to zero. The early fringe cements as the clay 


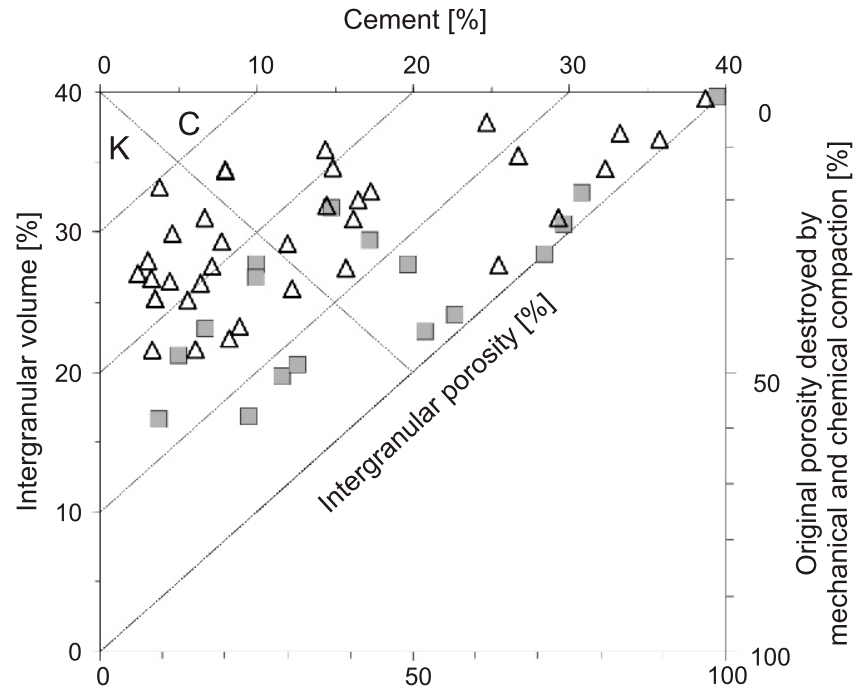

Original porosity destroyed by cementation [\%]

$\Delta$ samples in the western part of the study area

$\square$ samples in the eastern part of the study area

Fig. 10. Plot of porosity data for the Miocene sandstones on a diagram after Houseknecht (1987) showing the effect of compaction and cementation on porosity: $\mathrm{C}$ - cementation predominance, $\mathrm{K}$ - compaction predominance

rims and the quartz overgrowths bound the sediment, that prevented mechanical compaction, and resulted in a preservation of a part of the primary porosity. The plot of the total intergranular volume versus the cement volume (Houseknecht, 1987) reveals that the cementation has been more important in the porosity destruction than the compaction (Fig. 10). The primary porosity was reduced on average due to compaction and cementation by about 26 and $35 \%$, and by approximately 36 and $43 \%$ in the western and eastern parts, respectively (Fig. 10). The dissolution affects the porosity resulting in the formation of secondary porosity. This process exerted an effect mostly on the feldspar and lithic grains, and also on the carbonate cement. Some increase in porosity was also caused by a decay of the soft parts of the organisms.

\section{CONCLUSIONS}

1. The Middle Miocene sandstones of the Carpathian basin represent very fine to medium-grained subarkosic and sublithic arenites and wackes. Their detrital framework is dominated by quartz, feldspar and subordinate rock fragments, micas, glauconite and bioclasts. The dominant recognized cement types are: Fe-bearing calcite, quartz overgrowths, dolomite and ankerite, and kaolinite. K-feldspar overgrowths, chlorite/chlorite-smectite rims, illite, pyrite, siderite, anhydrite and rhodochrosite are minor cements of the sandstones. Siderite and rhodochrosite have been recognized only in the west, and anhydrite in the east.

2. The $\delta^{18} \mathrm{O}_{\text {VPDB }}$ data $(-8.8$ to $-1.7 \%$ ) of the dolomite and the coarsely crystalline calcite indicate that the carbonate cements precipitated from the porewater with the $\delta^{18} \mathrm{O}_{\text {vsmow values be- }}$ tween $\sim-3.0$ to $3.0 \%$ which points to a mixture of marine and meteoric waters. The $\delta^{13} \mathrm{C}_{\mathrm{VPDB}}$ values of carbonates $(-7.8$ to $2.1 \%$ ), suggest derivation of carbon from microbial methanogenesis of organic matter. The ${ }^{87} \mathrm{Sr} /{ }^{86} \mathrm{Sr}$ values (0.7087 to 0.7093$)$ in coarsely crystalline calcite, higher than in Badenian seawater, suggest that pore-fluid had interacted with continental silicates.

3. Fluid inclusions give in general temperatures $<60^{\circ} \mathrm{C}$ (at maximum $80^{\circ} \mathrm{C}$ ) for the calcite cements, and pressures of about 375 bars. The fluid was $\mathrm{CO}_{2}$-bearing, of moderate salinity (of $\sim 10 \%$ and $\sim 13 \mathrm{wt} . \% \mathrm{NaCl}$ eq.), of moderate isotopic composition and with a density of $\sim 1.1 \mathrm{~g} / \mathrm{cm}^{3}$. Petrographic and isotopic studies of cements in the sandstones suggest that the Middle Miocene deposits underwent diagenetic processes at temperatures not higher than $100^{\circ} \mathrm{C}$.

4. Most Middle Miocene sandstones show a good and a very good porosity of about $20 \%$ and permeability $>100 \mathrm{mD}$. The porosity reduction appears to be depth-controlled; the porosity data show a general decrease with an increase in depth. Both primary intergranular and secondary intragranular and intercrystalline pore types are present in the sandstones. Primary pores are abundant and are affected by compaction and cementation by about 26 and $35 \%$ in the west, as well as by approximately 36 and $43 \%$ in the east, respectively. Some increase in porosity was caused by the dissolution of detrital grains (mainly feldspars) and by the decay of soft parts of organisms. Comparing the sandstones from the western and eastern parts of the Carpathian Foredeep, the first ones show better filtration abilities.

5 . The history of diagenesis of the Middle Miocene sandstones in the basin studied includes two stages: eo- and mesodiagenesis. Mechanical compaction (crystallisation of chlorite /chlorite-smectite, microcrystalline calcite, pyrite, siderite, kaolinite and quartz cements), as well as the dissolution of feldspars and micas correspond to eodiagenesis. The cementation of the following minerals: K-feldspar, dolomite and ankerite, coarsely crystalline calcite and illite as well as albitisation, and the dissolution of feldspar grains and carbonate cements correspond to mesodiagenesis.

Acknowledgements. Part of the research was undertaken as project No. UKRAINA/193/2006 of the Ministry of Science and Higher Education carried out at the AGH University of Science and Technology and in the Polish Geological Institute National Research Institute financed from the scientific funds of 2007-2010. The research was also supported by funds of the PGI-NRI, Warsaw. Thanks are due to Prof. A. Maliszewska for her suggestions and fruitful discussions concerned with the essence of the subject. T. Peryt is thanked for his editorial revisions. Cordial thanks are addressed to D.I. Céndon, K. Górniak, G. Leśnak and one anonymous reviewer, whose critical comments, detailed revisions and stimulating suggestions significantly improved the manuscript. 


\section{REFERENCES}

Andreyeva-Grigorovich, A.S., Oszczypko, N., Ślączka, A., Oszczypko-Clowes, M., Savitskaya, N. A., Trofimovicz, N., 2008. New data on the stratigraphy of the folded Miocene Zone at the front of the Ukrainian Outer Carpathians. Acta Geologica Polonica, 58: 325-353.

Armstrong-Altrin, J.S., II Lee, Y., Verma, S.P., Worden, R.H., 2009. Carbon, oxygen, and strontium isotope geochemistry of carbonate rocks of the upper Miocene Kudankulam Formation, southern India: implications for paleoenvironment and diagenesis. Chemie der Erde, 69: 45-60.

Bakker, R.J., 2003. Package FLUIDS 1. Computer programs for analysis of fluid inclusion data and for modelling bulk fluid properties. Chemical Geology, 194: 3-23.

Bodnar, R.J., 1990. Petroleum migration in the Miocene Monterey Formation, California, USA: constraints from fluid inclusion studies. Mineralogical Magazine, 6: 295-304.

Boles, J.R., Franks, S.G., 1979. Clay diagenesis in Wilcox sandstones of Southwest Texas: implications of smectite diagenesis on sandstones cementation. Journal of Sedimentary Petrology, 49: 55-70.

Brown, P., 1982. FLINCOR: a microcomputer program for the reduction and investigation of fluid inclusion data. American Mineralogist, 74: 1390-1393.

Burns, S.J., Baker, P.A., Showers, W.J., 1988. The factors controlling the formation and chemistry of dolomite in organic-rich sediments: Miocene Drakes Bay Formation, California. SEPM Special Publications, 43: 41-52.

Burruss, R.C., 1987. Diagenetic paleotemperatures from aqueous fluid inclusions: reequilibration of inclusions in carbonate cements by burial heating. Mineralogical Magazine, 51: 477-481.

Céndon, D.I., Ayora, C., Pueyo, J.J., Taberner, C. Blanc-Valleron, M., 2008. The chemical and hydrogeological evolution of the Mulhouse potash basin (France): Are "marine" ancient evaporites always representative of synchronous seawater chemistry? Chemical Geology, 252: 109-124.

Choquette, P.W., Pray L.C., 1970. Geologic nomenclature and classification of porosity in sedimentary carbonates. AAPG Bulletin, 54: 207-220.

Czapowski, G., 1976. Several kinds of carbonate cementation in Miocene sediments in the vicinity of Sandomierz (Holy Cross Mts., Central Poland). Bulletin de l'Academie Polonaise des Sciences, Série de les Sciences de la Terre, 24: 83-92.

Dickson, J.A.D., Montańez, I.P., Saller, A.H., 2001. Hypersaline burial diagenesis delineated by component isotopic analysis, late Paleozoic limestones, west Texas. Journal of Sedimentary Research, 71: 372-379.

Dutton, S.P., Land, L., 1985. Meteoric burial diagenesis of Pennsylvanian arkosic sandstones, Southwestern Anadarko Basin, Texas. AAPG Bulletin,69: 22-38.

Dziadzio, P., 2000. Depositional sequences in Badenian and Sarmatian deposits in the SE parts of the Carpathian Foredeep (SE Poland) (in Polish with English summary). Przeglą Geologiczny, 46: 1124-1138.

El-Ghali, M.A.K., El Khoriby, E., Mansurberg, H., Morad, S., Ogle, N., 2013. Distribution of carbonate cements within depositional facies and sequence stratigraphic framework of shoreface and deltaic arenites, Lower Miocene, the Gulf of Suez rift, Egypt. Marine and Petroleum Geology, 45: 267-280.

Fedyshyn, V.O., ed., 1998. Atlas of Oil and Gas Fields of Ukraine. Ukrainian Oil and Gas Academy, Lviv.

Friedman, I., O'Neil J., 1977. Compilation of stable isotope fractionation factors of geochemical interest. USGS Professional Paper, 440-K: 1-12.

Galamay, A.R., Meng, F., Bukowski, K., 2014. Sulphur isotopes in anhydrite from Badenian (Middle Miocene) salts of the Hrynivka area (Ukrainian Carpathian Foredeep). Geological Quarterly, 58 (3): 439-448.
Garcia-Veigas, J., Céndon, D.I., Rosell, L., Orti F., Torres- Ruiz, J., Martin, J.M., Sanz, E., 2013. Salt deposition and brine evolution in the Granada Basin (Late Tortonian, SE Spain). Palaeogeography, Palaeoclimatology, Palaeoecology, 369: 452-465.

Garcia-Veigas, J., Rosell, L., Céndon, D.I., Gilbert, L., Martin, J.M., Torres- Ruiz, J., Orti F., 2015. Large celestine orebodies formed by early-diagenetic replacement of gypsified stromatolites (Upper Miocene, Montevive-Escuzar deposit, Granada Basin, Spain). Ore Geology reviews, 64: 187-199.

Garecka, M., Olszewska, B., 2011. Correlation of the Middle Miocene deposits in SE Poland and West Ukraine based on foraminifera and calcareous nannoplankton. Annales Societatis Geologorum Poloniae, 81: 309-330.

Glasmann, J.R., Lundegard, P.D., Clark, R.A., Penny, B.K., Collins, I.D., 1989. Geochemical evidence for the history of diagenesis and fluid migration: Brent sandstone, Heather field, North Sea. Clay Minerals, 24: 255-284.

Hałas, S., 1982. Isotopic studies of sulphates, carbonates and crystallization waters of gypsum in the Miocene deposits in the Carpathian Foredeep (in Polish with English summary). Przegląd Geologiczny, 30: 73-76.

Hodell, D.A., Mueller, P.A., Garrido J.R., 1991. Variations in the strontium isotopic composition of seawater during the Neogene. Geology, 19: 24-27.

Houseknecht, D.W., 1987. Assessing the relative importance of compaction processes and cementation to reduction of porosity in sandstones. AAPG Bulletin, 71: 633-642.

Jarmołowicz-Szulc, K., Kozłowska, A., Kuberska, M., 2011. Temperature and isotopic relations in the Middle Miocene sandstones from the Ukrainian Carpathian Foredeep Basin - a reconnaissance study. Annales Societatis Geologorum Poloniae, 81: 79-86.

Jasionowski, M., Peryt, T.M., 2010. Isotopic compositions of dolomite associated with Middle Miocene Badenian anhydrites in the Carpathian Foredeep basin of SE Poland. Geological Quarterly, 54 (4): 533-548.

Jasionowski, M., 1997. Outline of lithostratigraphy of the Miocene deposits in the eastern part of the Carpathian Foredeep (in Polish with English summary). Biuletyn Państwowego Instytutu Geologicznego, 373: 43-60.

Jasionowski, M., Peryt, T.M., Wysocka, A., Poberezhskyy, A.V., 2012. Marginal facies of Badenian and Lower Sarmatian of the Fore-Carpathian Basin in SE Poland in SE Poland and western Ukraine - results of research during the last two decades (in Polish with English summary). Biuletyn Państwowego Instytutu Geologicznego, 449: 71-86.

Jenyon, M.K., 1990. Oil and Gas Traps. Aspects of their Seismostratigraphy, Morphology and Development. John Wiley and Sons.

Kalyuzhnyi, V.A., 1982. The Principles of Studies of the Mineral-forming Fluids (in Russian). Naukova Dumka, Kiev.

Kantorowicz, J.D., 1990. The influence of variations in illite morphology on the permeability of Middle Jurassic Brent Group sandstones, Cormorant Field, UK North Sea. Marine and Petroleum Geology, 7: 66-74.

Karnkowski, P., 1999. Oil and Gas Deposits in Poland. GEOS, Kraków.

Kasprzyk, A., Pueyo, J.J., Hałas, S., Fuenlabrada, J.M., 2007. Sulphur, oxygen and strontium isotope compositions of the Middle Miocene (Badenian) calcium sulphates from the Carpathian Foredeep, Poland: palaeoenvironmental implications. Geological Quarterly, 51 (3): 285-294.

Kotarba, M.J., Koltun, Y.V., 2006. Origin and habit of hydrocarbons of the Polish and Ukrainian parts of the Carpathian province. AAPG Memoir, 84: 395-443.

Kotarba, M.J., Więcław, D., Koltun, Y.V., Marynowski, L., Kuśmierek, J., Dudok, I.V., 2007. Organic geochemical study and genetic correlation of natural gas, oil and Menilite Source 
rocks in the area between San and Stryj rivers (Polish and Ukrainian Carpathians). Organic Geochemistry, 40: 1431-1456.

Kotarba, M.J., Peryt, T.M., Koltun, Y.V., 2011a. Microbial gas system and perspectives of hydrocarbon exploration in Miocene strata of Polish and Ukrainian Foredeep. Annales Societatis Geologorum Poloniae, 81: 523-548.

Kotarba, M.J., Więcław, D., Kosakowski, P., Wróbel, M., Matyszkiewicz, J., Buła, Z., Krajewski, M., Koltun, Y.V., Tarkowski, J., 2011b. Petroleum systems in the Palaeozoic-Mesozoic basement of the Polish and Ukrainian parts of the Carpathian Foredeep. Annales Societatis Geologorum Poloniae, 81: 487-522.

Kozłowska, A., Kuberska, M., Lis, P., Maliszewska, A., 2011. Diagenesis and reservoir properties of the Middle Miocene sandstones in the Polish segment of the Carpathian Foredeep. Annales Societatis Geologorum Poloniae, 81: 87-103.

Krzywiec, P., Oszczypko, N., Bukowski, K., Oszczypko-Clowes, M., Śmigielski, M., Stuart, F.M., Persano, C., Sinclair, H.D., 2014. Structure and evolution of the Carpathian thrust front between Tarnów and Pilzno (Pogórska Wola area, southern Poland) - results of integrated analysis of seismic and borehole data. Geological Quarterly, 58 (3): 409-426.

Kuberska, M., Kozłowska, A., Lis, P., 2011. Petrographic characteristic of the Middle Miocene sediments in the Ukrainian segment of the Carpathian Foredeep. Annales Societatis Geologorum Poloniae, 81: 351-361.

Kurovets, I., Prytulka, G., Shpot, Y., Peryt, T.M., 2004. Middle Miocene Dashava Formation sandstones, Carpathian Foredeep, Ukraine. Journal of Petroleum Geology, 27: 373-388.

Kurzawa, M., 1990. The early diagenesis influence on forming of physical properties of Miocene biodetrital limestones from Roztocze hills (in Polish with English summary). Kwartalnik Geologiczny, 34 (3): 369-392.

Levorsen, A.I., 1956. Geology of Petroleum. Freeman and Comp, San Francisco.

Lis, P., Wysocka, A., 2012. Middle Miocene deposits in Carpathian Foredeep: facies analysis and implications for hydrocarbon reservoir prospecting. Annales Societatis Geologorum Poloniae, 82: 239-253.

Maliszewska, A., Kozłowska, A., Kuberska, M., 2001a Diagenesis of the Miocene sediments from Tarnogród area (Carpathian Foredeep). Biuletyn Państwowego Instytutu Geologicznego, 396: 102-103.

Maliszewska, A., Kozłowska, A., Kuberska, M., 2001b. The Miocene siliciclastic deposits from the Tarnogród area (Carpathian Foredeep, SE Poland) and their reservoir properties (in Polish with English summary). Przegląd Geologiczny, 49: 436-440.

Maliszewska, A., Kozłowska, A., Kuberska, M., 2004. An influence of the diagenesis on the porosity of the Miocene sandstones in the Tarnogród region (the Carpathian Foredeep) (in Polish with English summary). Prace Instytutu Nafty i Gazu, 130: 97-101.

McArthur, J.M., Howarth, R.J., Bailey, T.R., 2001. Strontium isotope stratigraphy: LOWESS Version 3: Best fit to the marine Sr-isotope curve for 0-509 Ma and accompanying look-up table for deriving numerical age. Journal of Geology, 109: 155-170.

McCrea, J.M., 1950. On the isotopic geochemistry of carbonates and a paleotemperature scale. Journal of Chemical Physics, 18: 849-857.

Milliken, K.L., 1998. Carbonate diagenesis in non-marine foreland sandstones at the western edge of the Alleghanian overthrust belt, Southern Appalachians. IAS Special Publication, 26 87-105.

Morad, S., 1998. Carbonate cementation in sandstones: distribution patterns and geochemical evolution. IAS Special Publication, 26: 1-26.
Ney, R., Burzewski, W., Bachleda, T., Górecki, W., Jakóbczak, K., Słupczyński, K., 1974. Outline of paleogeography and evolution of lithology and facies of Miocene layers on the Carpathian Foredeep (in Polish with English summary). Prace Geologiczne, 82: 7-64.

Osborne, M., Haszeldine, R.S., Fallick, A.E., 1994. Variation in kaolinite morphology with growth temperature in isotopically mixed pore-fluids, Brent Group, UK North Sea. Clay Minerals, 29: 591-608.

Oszczypko, N., Krzywiec, P., Papadyuk, I., Peryt, T., 2006. Carpathian Foredeep Basin (Poland and Ukraine) - its sedimentary, structural and geodynamic evolution. AAPG Memoir, $\mathbf{8 4}$ 293-350.

Oslick, J.S., Miller, K.G., Feingenson, M.D., Wright, J.D., 1994 Oligocene-Miocene strontium isotopes: stratigraphic revisions and correlations to an inferred glacioeustatic record. Paleoceanography, 9: 427-443.

Palmer, M.R., Edmond, J.M., 1989. The strontium isotope budget of the modern ocean. Earth and Planetary Science Letters, 92: $11-26$.

Peryt, D., Gedl, P., Peryt, T.M., 2014. Foraminiferal and palynological records of the Late Badenian (Middle Miocene) transgression in Podolia (Shchyrets near Lviv, western Ukraine). Geological Quarterly, 58 (3): 465-484.

Peryt, T.M., 2006. The beginning, development and termination of the Middle Miocene Badenian salinity crisis in Central Paratethys. Sedimentary Geology, 188-189: 379-396.

Peryt, T., 2012. Zarys budowy geologicznej zapadliska przedkarpackiego (in Polish). In: Geothermal Atlas of the Carpathian Foredeep (ed. W. Górecki): 24-36. AGH, Kraków.

Peryt, T.M., Anczkiewicz, R., 2015. Strontium isotope composition of Middle Miocene primary gypsum (Badenian of the Polish Carpathian Foredeep Basin): evidence for continual non-marine inflow of radiogenic strontium into evaporite basin. Terra Nova, 27: $54-61$.

Peryt, T., Piwocki, M., 2004. Budowa Geologiczna Polski, 1. Stratygrafia. Część 3a, Kenozoic, Paleogen i Neogen (in Polish). Państwowy Instytut Geologiczny, Warszawa.

Peryt, T.M., Hryniv, S.P., Anczkiewicz, R., 2010. Strontium isotope composition of Badenian (Middle Miocene) Ca-sulphate deposits in West Ukraine: a preliminary study. Geological Quarterly, $\mathbf{5 4}$ (4): 465-476.

Pettijohn, F.J., Potter, P.E., Siever, R., 1972. Sand and Sandstone. New York, Springer.

Roedder, E., 1984. Fluid inclusions. Reviews in Mineralogy, 12.

Schultz, J.I., Boles, J.R., Tilton, G.R., 1989. Tracking calcium in the San Joaquin basin, California: a strontium isotopic study of carbonate cements at North Coles Levee. Geochimica et Cosmochimica Acta, 53: 1991-1999.

Sheppard, T.J., Rankin, AH., Alberton, D.H.M., 1985. A Principal Guide to FI Studies. Blackie, New York.

Sheppard, S.M.F., 1986. Characterization and isotopic variation in natural waters. Reviews in Mineralogy, 16: 165-181.

Thirlwall, M.F., 1991. Long-term reproducibility of multicollector $\mathrm{Sr}$ and $\mathrm{Nd}$ isotope ratio analysis. Chemical Geology (Isotope Geoscience Section), 94: 85-104.

Więcław, D., Kotarba, M.J., Kowalski, A., Koltun, Y.V., 2012. Origin and maturity of oils in the Ukrainian Carpathians and their Mesozoic basement. Geological Quarterly, 56 (1): 158-168.

Wysocka, A., Radwański, A., Górka, M., 2012. Mykolaiv Sands in Opole Minor and beyond: sedimentary features and biotic content of Middle Miocene (Badenian) sand shoals of Western Ukraine. Geological Quarterly, 56 (3): 475-492. 